\title{
INDIANA's MIDWIFERY STATUTE AND THE LEGAL BARRIERS THAT WILL RENDER IT UNWORKABLE
}

\author{
JOANNE ROUSE ${ }^{*}$
}

"If women lose the right to say where and how they birth their children, then they will have lost something that's as dear to life as breathing."

\section{INTRODUCTION}

The State of Indiana recently legalized certified direct entry midwifery. ${ }^{2}$ Surely the new law, championed as a "huge step forward for families in Indiana" 3 and the product of decades of lobbying efforts, ${ }^{4}$ would not merely maintain the status quo. ${ }^{5}$ Surely the new law, aimed to bring together two historically disparate groups, would not promote a greater resentment of one another. ${ }^{6}$ Surely the new law would not deprive Hoosier women of their United States Constitutional right to privacy or to the free exercise of their religion. ${ }^{7}$ Yet, the language of the new midwifery statute produces these results that surely no law should produce.

Behind the portrayal of this law as a giant leap for midwife accessibility in Indiana, however, is the strong likelihood that very few aspiring midwives will be able to comply with the requirements needed to practice legally in the State of Indiana. ${ }^{8}$ Two provisions, in particular, will produce an unworkable statute: the

* J.D. Candidate, Indiana University Robert H. McKinney School of Law, 2015; B.A., Marquette University, 2011. I would like to thank Professor Wright, for his invaluable insight and guidance throughout my note writing process, and my family for their unending love and support.

1. Ami McKay, The Birth House 361 (reprint ed. 2007).

2. H.B. 1135, 118th Leg., 1st Sess. (Ind. 2013), available at http://www.in.gov/ apps $/$ lsa/session/billwatch/billinfo?year=2013\&session=1\&request $=$ getBill\&docno $=1135$, archived at http://perma.cc/6F22-A4F3. Midwifery is generally divided into two groups of practitioners. Certified Nurse Midwives obtain a nursing degree and, thereafter, receive advanced training in midwifery and have legal status in all fifty states. Direct Entry Midwives are educated in midwifery through a variety of routes, including a midwifery school, a program distinct from the study of nursing, or through apprenticeship, and their legal status varies from state-to-state. Indiana legalized "Certified Direct Entry Midwifery" in 2013, which is a variation of Direct Entry Midwifery. See infra Part II.B.1.

3. Maureen Hayden, New Law Legalizes Midwifery in Indiana, KOKOMO TRIB. (June 8, 2013), available at $\mathrm{http} / /$ kokomotribune.com/local/x1076949700/New-law-legalizes-midwifery-inIndiana, archived at http://perma.cc/XLS6-63N6.

4. Ellie Price, New Law Allows Non-Nurse Midwives to Practice in Indiana, STATEHOUSE FILE (June 18, 2013), http://thestatehousefile.com/new-law-allows-non-nurse-midwives-to-practicein-indiana/11904/, archived at http://perma.cc/BQ5B-ZJH6.

5. See infra Part III.

6. See infra Part I.A.2, III.

7. See Part II.B.3.

8. IND. CODE $§ 25-23.4-3-1(\mathrm{~b})(2)$ (2013) (“[A]n individual may not engage in the practice 
requirement that Certified Direct Entry Midwives ("CDEMs") must have a "collaborating agreement" with a physician" and the requirement that CDEMs must maintain sufficient liability insurance in order to become certified. ${ }^{10}$ Because the statute does not provide immunity or any liability protection for collaborating physicians, very few physicians will be willing to enter into the collaborative agreement. ${ }^{11}$ Furthermore, it is unlikely that many CDEMs will be able to locate liability insurance at an affordable price. ${ }^{12}$ Although excited about the formal legalization of CDEMs in Indiana, Mary Ann Griffin, president of the Indiana Midwives Association, lamented that "only about a dozen midwives practicing in Indiana would likely qualify to be certified." 13

The purpose of this Note is to encourage the Indiana Legislature to amend its certified direct entry midwifery statute to eliminate the collaborative agreement with a physician requirement and the liability insurance requirement. Thus, this Note first proposes an amendment to the statute that provides for full liability protection for physicians who choose to collaborate informally with CDEMs, and, second, proposes an amendment that encourages, but does not require, CDEMs to maintain sufficient liability insurance until the State can find such insurance at an affordable price.

Part I of this Note briefly explores the history of midwifery from colonial times to the present and explains why midwifery experienced a sharp decline in the early twentieth century. It explains the various types of midwives and differentiates between the medical model of care supported by physicians and the midwifery model of care endorsed by midwives. Part II reviews the statutory regulation and constitutional landscape in the United States for the sake of better understanding the likely effects of the Indiana statute. It highlights where midwifery regulation currently stands, how various approaches to regulation compare to one another, and provides a detailed study of California midwifery legislation. Finally, Part III examines the strengths and weaknesses of Indiana's certified direct entry midwifery statute. It proposes specific amendments by looking to the successes and failures of other regulatory schemes.

of midwifery unless . . . the individual has a Certified Direct Entry Midwife certificate ... and has a collaborative agreement with a physician ....").

9. Id. $\S 25-23.4-5-1$.

10. Id. $\S 25-23.4-3-1(\mathrm{c})(10)$; see also MiLton FrIEDMAN, CAPITALISM AND FREEDOM 141 (1962) ("In practice, the considerations taken into account in determining who shall get a license often involve matters that, so far as a layman can see, have no relation whatsoever to professional competence. This is not surprising. If a few individuals are going to decide whether other individuals may pursue an occupation, all sorts of irrelevant considerations are likely to enter.").

11. See infra Part III.B.

12. See infra Part III.B.

13. Hayden, supra note 3. 


\section{The History of Midwifery AND the Midwifery MOdel of CARE}

\section{A. The History of Midwives}

Understanding the origins of midwifery in the United States and the changes midwifery has experienced over the past 150 years greatly aids in determining the substance of a workable midwifery statute today. The midwives' story has been one of struggle for centuries. ${ }^{14}$ Despite the continued resistance, midwives have managed to remain a viable birthing option for women looking for an alternative to an obstetrician-attended hospital birth. ${ }^{15}$

1. Midwifery in Colonial America.-Midwives were the primary birth attendants, participating in nearly all births, in the original thirteen colonies of the United States. ${ }^{16}$ The colonial settlers brought the practice of midwifery to America from Europe where the midwife was the primary care provider during pregnancy, labor, and post-partum. ${ }^{17}$ As it was in Europe, midwifery remained a female-dominated profession in the colonies. ${ }^{18}$ Midwives trained primarily through apprenticeship under the guidance of a more experienced midwife. ${ }^{19}$ The use of a midwife during childbirth became imbedded in colonial culture and childbirth became a social and communal event in which female relatives, friends, and neighbors, in addition to the female midwife, took part. ${ }^{20}$

Childbirth was not considered a medical event. ${ }^{21}$ The use of midwives in the home was especially apt for colonial America due to the widespread, rural population and the rarity of hospitals. ${ }^{22}$ Physicians only attended the most

14. Sarah Anne Stover, Note, Born by the Woman, Caught by the Midwife: The Case for Legalizing Direct-Entry Midwifery in All Fifty States, 21 Health Matrix 307, 312-13 (2011).

15. Benjamin Grant Chojnacki, Note, Protecting Maternal Autonomy from the Living Room to the Delivery Room, 23 J.L. \& HeAlth 45, 47 (2010).

16. Lisa L. Chalidze, Misinformed Consent: Non-medical Bases for American Birth Recommendations as a Human Rights Issue, 54 N.Y.L. SCH. L. REV. 59, 66 (2010); see also Christopher Rausch, Note, The Midwife and the Forceps: The Wild Terrain of Midwifery Law in the United States and Where North Dakota is Heading in the Birthing Debate, 84 N.D. L. REV.219, 224 (2008) (noting that the practice of midwifery dates back much further than the early eighteenth century and positing that it may be the oldest health profession in history).

17. Jason M. Storck, A State of Uncertainty: Ohio's Deficient Scheme of Midwifery Regulation in Historical and National Context, 8 QUINNIPIAC HEALTH L.J. 89, 90 (2004).

18. Rausch, supra note 16, at 225.

19. Stacey A. Tovino, American Midwifery Litigation and State Legislative Preferences for Physician-Controlled Childbirth, 11 CARDOZO WOMEN's L.J. 61, 63 (2004).

20. Id.; see also Stover, supra note 14, at 313 (quoting JUDITH PENCE ROOKS, MIDWIFERY AND CHILDBIRTH IN AMERICA 3 (1997) (translating the English word "midwife" to literally mean "to be 'with woman' during childbirth")).

21. Tovino, supra note 19 , at 63.

22. Rachel A. D. Marquardt, Note, Balancing Babies, Birth, and Belief: A Legal Argument Against Planned Homebirth, 16 J. GENDER RACE \& JUST. 607, 609 (2013). 
difficult births requiring the surgical removal of the fetus. ${ }^{23}$ Physicians, however, did not have many drugs or surgical instruments available to them, and this lack of technology meant that there was little difference between the services offered by a physician and by a midwife. ${ }^{24}$ This relative equality in results and popular perception led to a "system of cooperation" "and "professional courtesy" between midwives and physicians for most of the eighteenth century. ${ }^{25}$ Additionally, many physicians practiced medicine only part time and held other occupations, such as land proprietorships and politics, ${ }^{26}$ and generally left midwives undisturbed to provide care for women in pregnancy and labor. ${ }^{27}$

2. The Rise of the Medical Profession to the Exclusion of Midwifery.-This "system of cooperation" in which midwives delivered nearly all children in the home during the eighteenth century gave way to a "system of exclusion" ${ }^{28}$ in which physicians delivered more than eighty percent of all children in hospitals by $1950 .{ }^{29}$ The reasons for this drastic change are two-fold: the rise of the medical profession and the shifting population demographic from rural to urban settings. ${ }^{30}$ The resulting system of exclusion fueled an intense rivalry between obstetricians and midwives that continues to some extent to the present day. ${ }^{31}$

Two reports on medical education, published in 1910 and 1912, ignited the rise of professionalized medicine in childbirth. ${ }^{32}$ These reports identified deficiencies in obstetrical training. ${ }^{33}$ After observing the Johns Hopkins Medical School's obstetrical training program, J. Whitridge Williams, Professor of Obstetrics, concluded that "the average practitioner, through his lack of preparation for the practice of obstetrics, may do his patients as much harm as the much-maligned midwife." "34 As alluded to by Williams, the male-dominated medical profession no longer regarded midwives as tolerable in the profession of childbirth. ${ }^{35}$ Technological advances such as anesthesia and obstetrical forceps available exclusively to physicians provided a visual point of reference to

23. Laura D. Hermer, Midwifery: Strategies on the Road to Universal Legalization, 13 HeALth Matrix 325, 335 (2003).

24. Tovino, supra note 19, at 64 .

25. Id. (quoting Laurel Thatcher Ulrich, A Midwife's Tale: The Life of Martha BALLARD, BASED ON HER DIARY, 1785-1812, 61 (1991)).

26. Id.

27. Rausch, supra note 16 , at 225-26.

28. Deborah M. Fisch, Baby Steps: The Changing Relationship Between Michigan Obstetricians and Certified Professional Midwives, 14 MARQ. ELDER'S ADVISOR 87, 89 (2012).

29. Rausch, supra note 16, at 226.

30. Chalidze, supra note 16 , at 67.

31. Id.

32. $I d$. at 68 .

33. Id.

34. Tovino, supra note 19, at 66 (quoting JUdith WALZER LEAVITT, Brought TO BeD: CHILD-REARING IN AMERICA, 1750-1950, 63 (1986)).

35. Rausch, supra note 16 , at 226. 
distinguish the practice of obstetrics from the practice of midwifery. ${ }^{36}$

To remedy the lack of training, the reports recommended that obstetric students perform significantly more deliveries in hospitals during their training. ${ }^{37}$ The combination of the urbanization of America, which resulted in a larger percentage of Americans in proximity to hospitals, and the mass immigration of poor Europeans, who were willing to use their delivery as a teaching tool for young doctors in exchange for free obstetrical services, was just the recipe for this recommended training. ${ }^{38}$ As such, obstetricians viewed midwives as direct competition for patients. ${ }^{39}$ One legal scholar aptly described the changing relationship between physicians and midwives: "the seeds for bitter conflict were sown early in the twentieth century between obstetricians - virtually all of them male and eager to ply their ever-growing surgical and technological skills - and midwives, virtually all of them female, already being marginalized by exclusion from the scientific fraternity." 40

Besides poor immigrants used as training tools, middle and upper class women were the first to regularly utilize obstetricians. ${ }^{41}$ Physicians cited the germ theory of disease transmission, which experienced increasing acceptance in the early nineteenth century, to explain why the home was not a safe environment for a woman to deliver her baby. ${ }^{42}$ Childbirth itself was regarded as a dangerous procedure that was safer and less painful under the care of an obstetrician in a hospital setting, a "fact" that appealed to women who were able to afford an obstetrician-attended hospital birth. ${ }^{43}$

Indeed, maternal mortality rates were as high as $600-700$ deaths per 100,000 childbirths in the early twentieth century. ${ }^{44}$ These numbers began to decline by the 1930s when hospital childbirths under the direction of an obstetrician gained popularity, and physicians convinced pregnant women that this trend proved that childbirth is a pathological act requiring their disease-oriented approach to care. ${ }^{45}$ This correlation between decreased maternal mortality rates and the use of medicine to the exclusion of midwifery, however, did not represent a causal relationship. ${ }^{46}$ Instead, the increased use of antibiotics around this time was

36. Id.

37. Chalidze, supra note 16 , at 68.

38. Storck, supra note 17 , at 93.

39. Id. at 92 .

40. Chalidze, supra note 16, at 68; see also FRIEDMAN, supra note 10, at 148 ("The most obvious social cost is that any one of these measures, whether it be registration, certification, or licensure, almost inevitably becomes a tool in the hands of a special producer group to obtain a monopoly position at the expense of the rest of the public.").

41. Tovino, supra note 19, at 67.

42. Storck, supra note 17 , at $92-93$.

43. Stover, supra note 14, at 315; see also infra Part II.B.2.

44. Hermer, supra note 23 , at 337.

45. Id. at 336-37.

46. Id. at 337-38. 
largely responsible for the decline in deaths during childbirth. ${ }^{47}$ The rate of maternal mortality declined at a similar rate in most other western countries, all with very different birth practices, suggesting that the type of childbirth attendant used had little to do with the decline of maternal mortality. ${ }^{48}$

Regardless of this misperception, the medical, disease-oriented approach to childbirth cemented itself in mainstream American culture. ${ }^{49} \mathrm{~A}$ few decades into the nineteenth century, the previous sentiment that childbirth was a joyous, natural, and communal event had vanished. ${ }^{50}$ The popular acceptance that an obstetrician delivered birth in a hospital was the only option for childbirth continued for the next half-century, with obstetricians establishing a nearmonopoly of all childbirth by the $1960 \mathrm{~s}^{51}$

3. The "Resurgence" of Midwifery.-Midwifery experienced resurgence among urban, suburban, and middle class white women in the $1970 \mathrm{~s}^{52}$ This grassroots movement championed the ideas of "natural childbirth," "prepared childbirth," and supportive care in the home by midwives. ${ }^{53}$ They protested the view that every pregnancy and childbirth was a disease requiring routine medical intervention and extended hospital stays. ${ }^{54}$ These beliefs echoed the larger efforts during this time for women to reclaim power over their bodies and retain bodily integrity. ${ }^{55}$ Even though this movement to resurge midwifery continues today, ${ }^{56}$ physicians still attended ninety-five percent of all births in 2000, seventy percent of which included normal childbirths and healthy women. ${ }^{57}$

\section{B. The Midwifery Model of Care vs. The Medical Model of Care}

Realizing and understanding the difference between the services midwives offer and the services obstetricians offer is essential to fully grasp the pitfalls of Indiana's Certified Direct Entry Midwifery legislation and postulate how it can

47. $I d$. at 337 .

48. Id. at 337-38.

49. Storck, supra note 17, at 93; see also infra Part II.B.2.

50. Storck, supra note 17, at 93 n.17.

51. Tovino, supra note 19 , at 67-68.

52. Hermer, supra note 23, at 339.

53. Stover, supra note 14 , at 316.

54. Marquardt, supra note 22, at 609; see, e.g., Marc A. Rodwin, Patient Accountability and Quality of Care: Lessons from Medical Consumerism and the Patients' Rights, Women's Health and Disability Rights Movements, 20 AM. J.L. \& MED. 147, 158 (1994) (“[W]omen were expected to be passive in child birth .... [M] others were often denied information, restrained while in labor, and sometimes drugged and strapped. To fit the schedules of doctors, births were often induced when not necessary; other times they were delayed by holding patients' legs together.”).

55. Marquardt, supra note 22, at 609.

56. Storck, supra note 17, at 96.

57. Kathlyn Marie Happe, Health and Welfare Chapter 303: Is California Edging Towards a "Consultive" Relationship Between Midwives and Physicians?, 32 MCGEORGE L. REV. 713, 71718 (2001). 
be improved. These various birth attendants, including physicians, Certified Nurse-Midwives, and Direct Entry Midwives, can all contribute to a woman's safe, positive birth experience. ${ }^{58}$ While the methods and philosophies are different among these birth attendants, particularly between physicians and midwives,${ }^{59}$ the infant and maternal mortality rates are quite similar. ${ }^{60}$ Legislation can greatly affect the birth attendants' relationships with one another, and, ideally, legislation will help create a cooperative environment in which physicians and all types of midwives work together to create a dual system of childbirth care. ${ }^{61}$

1. The Midwifery Model of Care.-Midwives prescribe to a "wellness approach," which emphasizes low-risk childbirth as a normal, natural process for women. ${ }^{62}$ Well-trained midwives are experts in screening and caring for normal pregnancies and low-risk births. ${ }^{63}$ They do not accept high-risk cases, like women with high blood pressure, women with previously complicated pregnancies, and women with a family history of childbirth difficulties. ${ }^{64}$ If a complication arises during labor, trained midwives should timely recognize the abnormality and safely transfer the woman to the hospital. ${ }^{65}$ For low-risk, normal cases, however, midwives are fully capable of safely caring for the mother and baby through the entire pregnancy and childbirth process. ${ }^{66}$

A main tenant of this holistic, wellness approach is that midwives encourage mothers during pregnancy and childbirth, rather than control them. ${ }^{67}$ Instead of focusing solely on the woman's uterus, midwives attend to the woman as a whole person. ${ }^{68}$ Midwives believe that a woman's social and psychological state can greatly affect her pregnancy and childbirth. ${ }^{69}$ To ensure that the woman is socially and psychologically healthy, a midwife inquires into the woman's expectations of her pregnancy and labor, her morals, beliefs, fears, hesitations, and desires. ${ }^{70}$ During childbirth, midwives prefer to watch and wait for physiologic processes to progress naturally and remain with the woman

58. See infra Part I.B.1-2.

59. Id.

60. See infra Part I.B.3.

61. See infra Part III.

62. Hermer, supra note 23, at 332.

63. Julie Harmon, Note, Statutory Regulation of Midwives: A Study of California Law, 8 WM. \& MARY J. WOMEN \& L. 115, 117 (2001).

64. Id.

65. Id.

66. Id. at 118 .

67. Rausch, supra note 16, at 226; see Stover, supra note 14, at 320 (noting midwives do not deliver babies but instead attend to the laboring woman and catch the baby; this difference in wording "recognizes that the pregnant woman's body is the mechanism that actually delivers the baby").

68. Hermer, supra note 23, at 332.

69. Id.

70. Stover, supra note 14 , at 320. 
throughout the entire birth process. ${ }^{71}$ This holistic approach to pregnancy and childbirth can make midwifery practice a time-intensive and relationshipintensive approach ${ }^{72}$ but also reduces liability. ${ }^{73}$

Despite the amount of time a midwife spends with each woman, midwifery services are significantly less expensive than a physician-attended labor in a hospital. ${ }^{74}$ The midwives' hands-off approach encourages midwives to place a great trust in the body's ability to safely deliver the baby and to use medical interventionist methods only when absolutely necessary. ${ }^{75}$ They do not allow the possibility of complications to "preempt all other values associated with the woman's experience of bearing and giving birth to a child." "76 The low rate of intervention, including the non-use of costly tests and equipment such as sonograms and fetal monitors, is the main reason for the cost-effectiveness of midwifery services. ${ }^{77}$

There are two general classifications of midwives: Certified Nurse-Midwives ("CNMs") and Direct-Entry Midwives ("DEMs"). ${ }^{78}$ CNMs first receive basic nursing education and become registered nurses. ${ }^{79}$ They must then obtain a Master's degree in nursing and pass the certification exam administered by the American Midwifery Certification Board. ${ }^{80}$ These requirements make CNMs the type of midwife with the "highest degree of traditionally accepted medical training." ${ }^{81}$ The vast majority of midwives are CNMs ${ }^{82}$ and they work almost exclusively in hospital settings. ${ }^{83}$ CNMs are licensed health care providers legally authorized to practice in all fifty states. ${ }^{84}$

In contrast, DEMs are "independent practitioner[s] educated in the discipline of midwifery through self-study, apprenticeship, a midwifery school, a college, or university-based program distinct from the discipline of nursing." ${ }^{, 5}$ These

71. Id.

72. Id.

73. Fisch, supra note 28, at 109; see also Harmon, supra note 63, at 121 (explaining that, in addition to the close personal relationship between midwife and pregnant mother, the fact that midwives only take low-risk cases contributes to midwives being involved in fewer malpractice cases than obstetrics).

74. Harmon, supra note 63, at 118.

75. Chojnacki, supra note 15 , at 48.

76. Stover, supra note 14, at 320 (quoting Judith P. Rooks, The Midwifery Model of Care, 44 J. NURSE-MidWIFERY 370, 370 (1999)).

77. Harmon, supra note 63, at 118.

78. Chojnacki, supra note 15 , at 49.

79. Hermer, supra note 23, at 333.

80. Marquardt, supra note 22, at 611 .

81. Hermer, supra note 23, at 333.

82. American College of Nurse-Midwives, Fact Sheet: Essential facts About Midwives 1 (2013) [hereinafter ACNM FACT SHEET].

83. Hermer, supra note 23, at 333.

84. ACNM FACT SHEET, supra note 82, at 1.

85. Become a Midwife, MidwIVES AlliAnCE OF N. AM., http://mana.org/about- 
midwives, more than CNMs, fully prescribe to the midwifery model of care and frequently attend homebirths. ${ }^{86}$ As each state has the power to enact laws to protect its citizens' health and safety, state laws vary in the legality, standards of practice, and requirements for licensure or certification of DEMs. ${ }^{87}$ Some DEMs either choose or are required to obtain certification through the North American Registry of Midwives ("NARM"). ${ }^{88}$ These midwives, known as Certified Professional Midwives ("CPMs"), establish competency "through training, education and supervised clinical experience, followed by successful completion of a skills assessment and written exam." ${ }^{\prime 9}$ Although Indiana's use of the term "Certified Direct Entry Midwife" is unique, CDEMs are a type of DEM with specific requirements for state certification. ${ }^{90}$ Some midwives, known as lay midwives, choose not to obtain state licenses but instead gain experience without formal training through apprenticeship and practice. ${ }^{91}$

2. The Medical Model of Care.-While the midwifery model of care embraces a "wellness" approach, ${ }^{22}$ the medical model of care embraces a "disease-oriented" approach. ${ }^{93}$ Because obstetrics views childbirth as an illness, rather than a natural process, its focus "was and remains the diagnosis and treatment of pathology: complications of pregnancy and management of diseases affecting pregnant women and the fetuses they carry." 94 Obstetricians believe that "no case is normal until it is over." 95 Because many problems can potentially arise during childbirth, obstetricians strongly encourage women to deliver in a hospital setting. ${ }^{96}$ This approach has also resulted in a high rate of obstetrical

midwives/become-a-midwife (last visited Oct. 12, 2014), archived at $\mathrm{http} / /$ perma.cc/L33R-RGTA.

86. Harmon, supra note 63, at 119-20.

87. See infra Part II.A.

88. Rausch, supra note 16 , at 224.

89. How to Become a CPM, N. AM. REGISTRY OF MIDWIVES, http://narm.org/certification/ how-to-become-a-cpm/ (last visited Oct. 12, 2014), archived at http://perma.cc/8HA4-LPWW.

90. See, e.g., AlaSka STAT. § 08.65 (2014) (using the term "Certified Direct-Entry Midwives" in the Alaska statute but requiring training and credentials similar to those required by NARM and different than those required by Indiana); see infra Part III.A.

91. Happe, supra note 57, at 716; see also Chojnacki, supra note 15, at 49-50 (noting that some lay midwives "avoid certification because they view the training as harmful or irrelevant, while others practice illegally in states that do not permit them to attend births").

92. See supra Part I.B.1.

93. Rausch, supra note 16 , at 227.

94. Hermer, supra note 23, at 330 (quoting RooKs, supra note 20, at 4).

95. Id.

96. Planned Home Birth, Committee Opinion No. 476 (The American College of Obstetrics and Gynecologists) at 3 (2011) [hereinafter ACOG Committee Opinion]; see also Jessica Reaves, Use of Midwives Rises, Challenging the State to Respond, N.Y. TIMES (Sept. 23, 2010), http://www.nytimes.com/2010/09/24/us/24cncmidwives.html?pagewanted=all\&_r=0, archived at http://perma.cc/35BG-A3LT (“'We just don't think home is a safe environment for delivery,' said Dr. Jacques Abramowicz . . . Fellow of the American College of Obstetrics and Gynecology. 'Childbirth is very dynamic, and it can be a very dangerous process. In the vast majority of cases, 
interventions. $^{97}$

Obstetricians have many patients to tend to at once, which means they periodically check in with the patients and rely on nurses and machines to monitor labor. ${ }^{98}$ Some women find the hospital experience to be a "medical, passive and alienating event." 99 By and large, however, childbirth in a hospital attended by an obstetrician continues to be the norm for the vast majority of American women. ${ }^{100}$

3. The Data.-Because the constitutionality of Direct Entry Midwifery regulation hinges on the presence of a legitimate state interest, ${ }^{101}$ it is important to examine the data regarding the public safety risks and benefits of midwifery. Even though midwifery has been around since colonial times, high-quality evidence surrounding this debate is relatively limited. ${ }^{102}$ Women working with a midwife or planning a homebirth have been reluctant to participate in clinical trials, so most of the data comes from observational studies. ${ }^{103}$ The low rates of midwife-attended births are definitive, however, and in 2011 , only $0.007 \%$ of births were attended by a DEM. ${ }^{104}$

One prospective cohort study surveyed the United States and Canada, where midwives are not well-integrated into the healthcare system, and evaluated the safety of homebirths involving DEMs. ${ }^{105}$ This study is one of the largest studies involving DEMs and homebirth, ${ }^{106}$ but the results are similar to other studies of the practice of midwifery. ${ }^{107}$ It found that women who planned a homebirth with

nothing happens. However, if an emergency occurs, it happens very fast - in two, three, four minutes."”).

97. Hermer, supra note 23, at 331; see, e.g., ACOG Committee Opinion, supra note 96, at 2 (including interventions such as epidural analgesia, electronic fetal heart rate monitoring, episiotomy, operative vaginal delivery, and cesarean delivery).

98. Hermer, supra note 23, at 331.

99. Id. at 331-32.

100. Storck, supra note 17, at 95-96.

101. See infra Part II.B.

102. ACOG Committee Opinion, supra note 96 , at 1 .

103. Id.

104. Joyce A. Martin et al., NAtional Vital Statistics Reports: Births: Final Data FOR 2011, U.S. DeP'T OF HEALTh AND HuMAN SERVICES: CENTER FOR DisEASE CONTROL AND PREVENTION Table 20 (2011) (finding that ninety-one percent of births were attended by a physician and $0.08 \%$ were attended by a CNM).

105. Kenneth C. Johnson \& Betty-Anne Daviss, Outcomes of Planned Home Births with Certified Professional Midwives: Large Prospective Study in North America, 330 BRITISH MED. J. 1416, 1416 (2005).

106. Id. at 1419-20.

107. See, e.g., A. Mark Durand, The Safety of Home Birth: The Farm Study, 82(3) AM. J. PuB. HEALTH 450, 451 (1992) (finding there was no significant difference between homebirth and hospital birth regarding fetal and neonatal death or labor-related complications); Patricia A. Janssen et al., Licensed Midwife-Attended, Out-of-Hospital Births in Washington State: Are They Safe?, Abstract, 21 BIRTH 141, 141-48 (1994) (finding no significant differences between out-of-hospital 
a DEM experienced low rates of intrapartum and neonatal mortality, similar to rates of low-risk births in a hospital setting. ${ }^{108}$ There were no maternal deaths. ${ }^{109}$ The study also found that rates of medical intervention in a midwife-assisted birth at home were less than half those in a hospital setting. ${ }^{110}$ The authors recommended increasing accessibility to DEMs for pregnant women. ${ }^{111}$

Advocates of both the midwifery model and the medical model agree that use of interventions in labor and delivery are much higher among physician-attended childbirth than DEM-attended childbirth. ${ }^{112}$ Midwifery advocates contend that "most obstetrical interventions during labor and delivery have little, if any, [positive] effect on the majority of the causes of maternal and neonatal morbidity and mortality." 113 Furthermore, these advocates explain that some intervention methods, such as regular use of cesarean sections, are dangerous and result in increased maternal morbidity. ${ }^{114}$ The medical community defends its use of intervention procedures. The American College of Obstetrics and Gynecology ("ACOG") claims that the goal of intervention methods is to "improve the health of children by intervening before birth to correct or treat prenatally diagnosed abnormalities," but it stresses that no intervention can be performed without the mother's informed consent. ${ }^{115}$ A national nursing organization explains that electronic fetal monitoring is an "appropriate and effective method[] to assess and promote maternal and fetal well-being."

Regardless of the benefit or harm of intervention procedures, the use of these methods in an obstetrician-attended birth results in significantly higher costs to

births attended by midwives and physician-attended births in a hospital); but see Jenny W.Y. Pang et al., Outcomes of Planned Home Births in Washington State: 1989-1996, 100 OBSTETRICs \& GYNECOLOGY 253, 253 (2002) (finding that planned homebirths had greater infant and maternal risks than did hospital births).

108. Johnson \& Daviss, supra note 105, at 1419.

109. Id. at 1417 .

110. Id. at 1419 ("Compared with the relatively low risk hospital group, intended home births were associated with lower rates of electronic fetal monitoring [9.6\% versus $84.3 \%$ ], episiotomy $[2.1 \%$ versus $33.0 \%]$, cesarean section $[3.7 \%$ versus $19.0 \%]$, and vacuum extraction $[0.6 \%$ versus $5.5 \%] . ")$.

111. Id. at 1421.

112. See ACOG Committee Opinion, supra note 96, at 2; Stover, supra note 14, at 328.

113. Hermer, supra note 23, at 342.

114. Id.

115. Maternal-Fetal Intervention and Fetal Care Center, Committee Opinion No. 501 (The American College of Obstetrics and Gynecologists), at 1 (2011); see Stover, supra note 14, at 329 (claiming that "[p]hysician and institutional convenience, the incentives of a fee-for-service payment system, the adverse effects of the malpractice system, limited reliance on best-evidence maternity guidelines, and reliance on obstetric specialists to provide care in the normal pregnancy are all frequently cited as the reasons for high intervention rates in low-risk births in hospital settings").

116. Fetal Heart Monitoring, Ass'N Of Women's Health, Obstetric and NeOnatal NURSES 1 (2008). 
mothers than a midwife-attended birth. ${ }^{117}$ The prospective cohort study, explained above, noted that "an uncomplicated vaginal birth in a hospital in the United States cost[s] on average three times as much as a similar birth at home with a midwife." ${ }^{118}$ Childbirth is the most common reason for hospitalization, ${ }^{119}$ with over 3.9 million women giving birth in hospitals. ${ }^{120}$ Furthermore, the scope of midwifery services is much greater than that of obstetric services, which makes the former a more cost-efficient endeavor for low-risk patients than the numbers would suggest. ${ }^{121}$

4. Can the Midwifery Model and the Medical Model Be Reconciled?-It is obvious, then, that obstetricians and DEMs view childbirth differently. ${ }^{122}$ Obstetricians prefer to be prepared for any complications that may arise, while midwives structure their practice on the view that childbirth is a normal, natural process. ${ }^{123}$ One approach, however, is not necessarily always superior. Rather, the midwifery model and the medical model operate best when working in cooperation with the other in a dual system of care. ${ }^{124}$ Ideally, obstetricians care for women with high-risk pregnancies in a hospital setting, and DEMs care for women with low-risk pregnancies in the home. ${ }^{125}$ The obstetrics community is now more open to the idea of formally trained DEMs attending to women with low-risk pregnancies than it has been in the past. ${ }^{126}$ ACOG explained that while "hospitals and birthing centers are the safest setting for birth, it respects the right of a woman to make a medically informed decision about delivery." 127 As Indiana has traditionally been a very physician-friendly state, ${ }^{128}$ it is particularly important for the Indiana legislature to craft legislation that can foster a cooperative relationship between obstetricians and CDEMs. ${ }^{129}$

117. Amy F. Cohen, Note, The Midwifery Stalemate and Childbirth Choice: Recognizing Mothers-to-Be as the Best Late Pregnancy Decisionmakers, 80 IND. L.J. 849, 851 (2005).

118. Johnson \& Daviss, supra note 105, at 1420.

119. Rebecca A. Spence, Abandoning Women to Their Rights: What Happens When Feminist Jurisprudence Ignores Birthing Rights, 19 CARDOZO J.L. \& GENDER 75, 78 (2012).

120. MARTIN ET AL., supra note 104, at Table 20.

121. See supra Part I.B.1

122. See supra Part I.B.1-2.

123. See supra Part I.B.1-2.

124. Fisch, supra note 28, at 117-18.

125. Id. at 116 (explaining the Netherland's dual system of care for childbirth).

126. See Hermer, supra note 23, at 335 (quoting Joseph B. DeLee, Progress Toward Ideal Obstetrics, 6 TRANSACTIONS AM. Ass'N FOR THE STUDY AND PREVENTION OF INFANT MORTALITY 114-23 (1915) (“The midwife is a relic of barbarism.")).

127. ACOG Committee Opinion, supra note 96, at 1.

128. Bob Keaveney, Physician-Friendly States, Physicians Practice (July 1, 2003) http://www.physicianspractice.com/articles/physician-friendly-states (last visited Oct. 12, 2014), archived at http://perma.cc/XH86-MY9J.

129. See infra Part III.B. 


\section{STATUTORY REGULATION AND CONSTITUTIONAL IMPLICATIONS}

Surveying the statutory and constitutional landscape of DEMs throughout the country will aid one's ability to discern why Indiana's CDEM statute should be amended and why the state legislature should be tasked with amending the statute. Each state has the power to craft statutes to regulate the midwives who practice within its jurisdiction. ${ }^{130}$ Courts have used a rational basis standard to consider whether the statutes are rationally related to a legitimate state interest in healthy childbirth, ${ }^{131}$ but this Note proposes to heighten the level of review of the CDEM statute to strict scrutiny. ${ }^{132}$

\section{A. State-by-State Regulation of Direct-Entry Midwives}

As each state has the power to regulate the practice of direct entry midwifery, it is unsurprising that across the nation midwives experience varying degrees of friendliness and hostility from the legal system. ${ }^{133}$ States may permit DEMs to practice, prohibit DEMs from practice, regulate and restrict DEMs' practice, or leave the issue unaddressed. ${ }^{134}$

1. States That License, Certify, Register, or Permit Direct Entry Midwifery.-Three states, including Indiana, regulate DEMs through certification. ${ }^{135}$ Twenty-one states regulate DEMs through state licensure. ${ }^{136} \mathrm{~A}$ license is not required to practice in Oregon, ${ }^{137}$ but the state does regulate how a DEM becomes licensed. ${ }^{138}$ Colorado regulates DEMs by requiring DEMs to

130. Tovino, supra note 19, at 68; see generally supra Part II.B.1 (noting that CNMs are legal in all fifty states).

131. Hermer, supra note 23, at 327.

132. See Part II.B.3.

133. Midwives Alliance of N. Am. \& N. Am. Registry of Midwives, Direct-Entry Midwifery State-by-State Legal Status, NARM.ORG (Aug. 8, 2013), at narm.org/pdffiles/statechart080213.pdf, archived at http://perma.cc/N5CB-735C [hereinafter State Legal Status].

134. Hermer, supra note 23 , at 353-59.

135. IND. CODE $\S \S 25-23.4-1-1$ to -8-1 (2013); N.H. REV. STAT. ANN $\S \S 326-D: 1$ to -D:14 (2013); TENN. CODE ANN. §§ 63-29-101 to -116 (2013).

136. Alaska Stat. $§ 08.65 .050$ (2013); ArIz. ReV. Stat. ANN. $\S 36-751$ to -759 (2013); ARK. CodE ANN. §§ 17-85-102 to -107 (2013); CA. Bus. \& Prof. CODE $\S ~ 2505-2521$ (West 2013); FLA. STAT. § 467.001 to -.209 (2013); IDAHO CODE ANN. § 54-5501 to -5513 (2013); LA. REV. STAT. ANN. §§ 37:3240 to -3259 (2013); MinN. StAT. §§ 147D.01-145D.27 (2013); MonT. CodE ANN. $\S \S 37-27-101$ to -325 (2013); N.J. STAT. ANN. $\S \S 45: 10-1$ to -22 (West 2013); N.M. STAT. ANN. § 24-1-3 (West 2013); N.Y. EDUC. LAW § 6958 (McKinney 2013); R.I. GEN. LAWS § 23-13-9 (2013); S.C. CodE ANN. §§ 44-89-10 to -100 (2013); TEX. CodE ANN. §§ 63-29-101- 53-29-116 (2013); UtAh Code ANN. $\S \S 58-77-101$ to -603 (West 2013); VT. STAT. ANN. TIT. 26, 4418104191 (2013); VA. CODE ANN. $\S \S 54.1-2957.7$ to -.13 (2013); WASH. REV. CODE $\S \S 18.50 .010$ to -.900 (2013); WIS. STAT. $\S 440.9805-44.9888$ (2013); WYO. STAT. ANN §§ 33-46-101 to -107 (2013).

137. OR. REV. STAT. $§ 687.415$ (2013).

138. Id. $\S \S 687.405$ to -.890 . 
register with the state, ${ }^{139}$ and Delaware requires DEMs to obtain a permit from the state. ${ }^{140}$ Twenty-six states, including Indiana, require DEMs practicing within its borders to pass the NARM exam as part of the regulating process. ${ }^{141}$

Indiana, Delaware, New Jersey, New York, and Tennessee require physician supervision of DEMs. ${ }^{142}$ California required this supervision until the State Legislature changed its code during the 2013 legislative session. ${ }^{143}$ The reasons why this requirement is problematic are explained in Parts II.B.2 and III. For now, it is helpful to explore the physician-DEM relationship in other state statutes.

Several state statutes encourage physicians and DEMs to foster cooperative relationships. A cooperative relationship is generally defined as "structural integration of [physicians and midwives] by means of formal protocol for interaction between them." ${ }^{144}$ This positive interaction, trust, and respect by both parties is key to creating a dual system of childbirth care for Hoosier women, and American women in general. ${ }^{145}$ Idaho, for example, begins its statutory regulation of DEMs by acknowledging the importance of the availability of midwifery services, in addition to obstetric services:

The legislature finds and declares that the practice of midwifery has been a part of the culture and tradition of Idaho since before pioneer days and that for personal, religious and economic reasons some Idaho citizens choose midwifery care. The purpose of this chapter is to preserve the rights of families to deliver their children in a setting of their choice, to provide additional maternity care options for Idaho's families, to protect the public health, safety and welfare and to provide a mechanism to assure quality care. ${ }^{146}$

Arkansas suggests that "[e]ach Licensed Lay Midwife is encouraged to develop a close working relationship with one or more specific Physician in obstetrical practice or CNM in obstetrical practice who agree to serve as a Referral source for the Lay Midwife. This relationship is optional." ${ }^{\prime 47}$ The relationship is not required for licensure, but it is encouraged. ${ }^{148}$ This dual system provides a woman with the opportunity to choose the midwifery model of care for her

139. Colo. ReV. StAT. $\S \S 12-37-101$ to -110 (2013).

140. Del. Code ANN. tit. $16 \S 122(3)(\mathrm{h})$ (2013).

141. State Legal Status, supra note 133.

142. 16 DEL. AdMIN. CODE $\S 4106(4.3)$ (2014); IND. CODE $§ 25-23.4-5$ (2014); N.J. ADMIN. CODE $§ 13: 35-2 A .6(2014)$; N.Y. EduC. LAW $§ 6958$ (McKinney 2014); TENN. CodE ANN. § 63-29115(a) (2014).

143. See infra Part II.A.2.

144. Fisch, supra note 28 , at 105.

145. Id. at 117-18.

146. IDAHO CODE ANN. § 54-5501 (2014).

147. Arkansas State Board of Health, Rules and Regulations for Governing the PRACTICE OF LAY MIDWIFERY IN ARKANSAS $§ 500$ (2008).

148. Id. 
childbirth experience while also assuring that, should a medical emergency or abnormality arise, a physician, who is familiar with her pregnancy, will be able to help.

Several statutes require DEMs to have a written plan to transfer patients to a physician or hospital in the event of emergencies. ${ }^{149}$ Minnesota requires applicants for licensure to develop a medical consultation plan, such as what conditions mandate consultation with a licensed health care provider, the transfer of care to a licensed health care provider, and emergency transfer to a hospital. ${ }^{150}$ The plan must meet certain criteria established by an independent organization endorsed by the state. ${ }^{151}$ Other states, such as Montana, require DEMs to "advise all women accepted for midwifery care to consult with a physician or certified nurse-midwife at least twice during the pregnancy." 152 Importantly, DEMs are not required to have a consultative relationship themselves with the physician or CNM but only have to advise their patients of the benefits of seeing another healthcare provider during pregnancy. ${ }^{153}$ These procedures are more typical than the physician collaboration requirement endorsed by Indiana, which requires a collaborating agreement for all patients, regardless of the low-risk or high-risk nature of the pregnancy. ${ }^{154}$

Several states make sure to include language that protects physicians from liability when receiving referral patients or emergency patients from DEMs. This liability protection fosters cooperative relationships, rather than encouraging physicians to view DEMs merely as an extremely costly liability. ${ }^{155}$ Louisiana, for example, prohibits licensed DEMs from providing care to patients who are deemed by physicians, after undergoing a risk assessment, to have high-risk pregnancies. ${ }^{156}$ The statute explicitly provides that the physician-patient relationship only exists for purposes of the risk assessment and does not continue

149. Hermer, supra note 23, at 354.

150. MinN. STAT. § 147D.11(a) (2014).

151. Id. at $\S 147 \mathrm{D} .11$ (b); see also COLO. REV. STAT. $\S$ 12-37-105(6) (2014) (“A direct-entry midwife shall prepare a plan, in the form and manner required by the director, for emergency situations. The plan must include procedures to be followed in situations in which the time required for transportation to the nearest facility capable of providing appropriate treatment exceeds limits established by the director by rule. A copy of such plan shall be given to each client as part of the informed consent required by subsection (5) of this statute.”); S.C. CODE ANN. REGS. 61-24 (1993) ("The Midwife must be able at all times to recognize the warning signs of abnormal or potentially abnormal conditions necessitating referral to a physician. It shall be the midwife's duty to consult with a physician whenever there are significant deviations from the normal.").

152. Mont. CODE ANN. § 37-27-315 (2014).

153. Id. $\S 37-27-101$ to -325 .

154. 16 DEL. AdMIN. CODE $§ 4106(4.3)$ (2014); IND. CODE § 25-23.4-5-1 (2014); N.J. ADMIN. CodE $\S 13: 35-2 A .6$ (2014); N.Y. Educ. LAW § 6958(2014); TENN. CodE ANN. § 63-29-115(a) (2014).

155. See infra Part I.A.2; see supra Part III.B.

156. LA. REV. STAT. ANN. § 37:3244(B) (2014). 
after the conclusion of that assessment. ${ }^{157}$ The risk assessment does not create a "legal relationship between the physician and the licensed midwife or any duty, responsibility, or obligation by the physician to supervise, collaborate, back-up, or oversee the licensed midwife's care of the patient." ${ }^{\text {"158 }}$ Although physicians may still be disinclined to work with DEMs for reasons other than liability, ${ }^{159}$ statutory protection from automatic various liability claims may push physicians and DEMs toward a more cooperative relationship. ${ }^{160}$ Furthermore, while the midwifery model of care itself shields DEMs from many lawsuits, ${ }^{161}$ if a DEM practices for long enough, the DEM will eventually be exposed to liability. As such, some states require DEMs to provide information regarding their liability insurance in the patient's informed consent form. ${ }^{162}$ It appears that Indiana is the only state to require DEMs to find and maintain sufficient liability insurance to practice. ${ }^{163}$

2. A Study of Midwifery Regulation in California.-The California State Legislature ("State Legislature") recently amended the state's midwifery statute to eliminate the physician supervision requirement for DEMs, and it is especially

157. Id. $\S 37: 3258(\mathrm{~A})$.

158. Id. § 37:3258(B)(2); see also FLA. STAT. § 467.017(2) (2014) (“Any physician . . . providing medical care or treatment to a woman or infant due to an emergency arising during delivery or birth as a consequence of the care received by a [direct-entry] midwife ... shall not be held liable for any civil damages as a result of such medical care or treatment unless such damages result from providing, or failing to provide, medical care or treatment under circumstances demonstrating a reckless disregard for the consequences so as to affect the life or health of another.”); IDAHO CODE ANN. § 54-5512 (2014) ("No physician, hospital, emergency room personnel, emergency medical technician or ambulance personnel shall be liable in any civil action arising out of any injury resulting from an act or omission of a licensed midwife, even if the health care provider has consulted with or accepted a referral from the licensed midwife. A physician who consults with a licensed midwife but who does not examine or treat a client of the midwife shall not be deemed to have created a physician-patient relationship with such client."); N.M. CODE R. $\S 16.11 .3 .12$ (D) (Lexis Nexis 2014) (“Any consultative relationship with a physician shall not by itself provide the basis for finding a physician liable for any acts or omissions by a licensed midwife.").

159. See supra Part I.B.4.

160. Fisch, supra note 28, at 111.

161. Id. at 109.

162. See, e.g., FLA. STAT. \$467.014(2014)(“A licensed midwife shall include in the informed consent plan presented to the parents the status of the midwife's malpractice insurance, including the amount of malpractice insurance, if any.”); WIS. STAT. \$440.985(2)(2014) (requiring a licensed midwife to provide client with information regarding "[w] $[\mathrm{w}$ ether the licensed midwife has malpractice liability insurance coverage and the policy of any such coverage"); see also COLO. REV.STAT. §§ 12-37-105(5)(a)(III)(E), 12-37-105(5)(a)(IV), 12-39-109(3) (2014) (requiring DEMs to inform patients whether or not they carry liability insurance until the state "finds that liability insurance is available at an affordable price, [then] registrants shall be required to carry such insurance").

163. IND. CODE $\S 25-23.4-3-1$ (c)(10) (2014). 
useful to review the evolution of California's law in this discussion about Indiana's statute. In 1993, the State Legislature enacted the California Licensed Midwifery Practice Act of 1993 ("CLMPA"), which professionalized non-nurse midwives for the first time in the State of California. ${ }^{164}$ The purpose of the law was to allow mothers to legally choose a midwife-assisted homebirth as a safe, cost-effective alternative to physician-attended hospital birth. ${ }^{165}$ The CLMPA defined the term midwifery and required midwives to work under the supervision of a licensed obstetrician. ${ }^{166}$ The term "supervision" was not meant to require the physical presence of the supervising obstetrician. ${ }^{167}$ This understanding of the physician supervision requirement is nearly identical to Indiana's physician collaboration requirement. ${ }^{168}$

The physician supervision requirement quickly proved to be an "unintended legal barrier which ha[d] rendered the legislation unworkable and unusable for California women and families." ${ }^{69}$ Many obstetricians were unwilling to supervise a DEM who would deliver babies primarily in the home. ${ }^{170}$ Even if a DEM could find an obstetrician who was not opposed to homebirths, most obstetricians would still be unable to supervise the DEM because their malpractice insurance carrier did not allow it. ${ }^{171}$

From 1993 through 2001, only one DEM was able to secure physician supervision. ${ }^{172}$ Many DEMs continued to attend homebirths anyway and some opted to refer patients to and collaborate with sympathetic physicians, although the collaboration was in an unofficial capacity to avoid liability concerns. ${ }^{173}$ One midwife explained her frustration: "[i]t prevents us from being in the system, where we want to be ... . Many of us have developed individual relationships with physicians that are happy to collaborate with us, who consult with us, who we work closely with, but it has to be underground." ${ }^{\prime 174}$ The law was so unworkable that even the Medical Board of California recognized the difficult position of DEMs and obstetricians, and, at times, refused to bring charges to

164. Tovino, supra note 19, at 95.

165. Kathlyn Marie Happe, Review of Selected 2000 California Legislation: Health and Welfare Chapter 303: Is California Edging Towards a "Consultive” Relationship Between Midwives and Physicians?, 32 MCGEORGE L. REV. 713, 713 (2001).

166. Tovino, supra note 19 , at 95.

167. Id.

168. See IND. CODE $§ 25-23.4-5-1$ (2014).

169. Letter from Corina Robles, Secretary-Treasurer, National Certified Professional Midwives, to Senator Liz Figueroa 1 (Feb. 28, 2000) (quoted in Happe, supra note 165, at 714).

170. Hermer, supra note 23, at 354.

171. Id.

172. Tovino, supra note 19 , at 95 (attributing this supervision to that fact that the DEM was also a physician's assistant).

173. Id. at 96 .

174. Jeremy B. White, California Midwives Push to Scrap Doctor-Supervision Requirement for Home-Births, SACRAMENTO BEE, July 18, 2013, at 1A. 
licensed DEMs practicing without a formal supervision agreement. ${ }^{175}$ The possibility of criminal prosecution still existed, however. ${ }^{176}$ In the end, it was California mothers who suffered because when they "choose the midwife model of care [they] dangerously separate themselves from the medical community entirely in order to ensure their midwife is not at risk of being caught engaging in an illegal activity." 177 In 2000, the State Legislature introduced an amendment to get rid of the physician supervision requirement, but this provision was defeated before the amendment became law. ${ }^{178}$

During the 2013 legislative session, the State Legislature abolished the physician supervision requirement. ${ }^{179}$ Under the revised law, the licensed DEM must have a written plan for referral of complications to a physician for consultation but does not need to identify a particular physician. ${ }^{180}$ If the DEM does need to consult with a physician for a complication or deviation from normal pregnancy, the consultation does not create a physician-patient relationship. ${ }^{181}$ If the physician determines that the complication will not render the pregnancy high-risk, the DEM may continue to be the primary care provider. ${ }^{182}$ These changes mean that physicians can freely consult with DEMs without liability concerns. ${ }^{183}$ The bill's sponsor, Assemblywoman Susan Bonilla, explained that "[t]his is a historic new law because it finally ensures that women who choose to have midwives deliver their babies will have the peace-of-mind knowing that proper safeguards are in place to provide them with physician care if necessary." 184 A representative from ACOG spoke out in support of the bill, stating that even though ACOG maintains that a hospital or birth center is the safest place for childbirth, she hoped this bill would make homebirth safer for California mothers. ${ }^{185}$

The new law will foster an effective, cooperative relationship between DEMs and physicians. ${ }^{186}$ This relationship brings California one step closer to a dual system of care, in which the midwifery model of care can offer a safe, costeffective alternative for low-risk pregnancies in the home setting. ${ }^{187}$ The California State Legislature's willingness to listen to the medical community,

175. Tovino, supra note 19 , at $96-97$.

176. Id. at 97 .

177. Happe, supra note 165 , at 723.

178. Tovino, supra note 19, at 97.

179. A.B. 1308, 2013-2014 Reg. Sess. (Cal. 2013).

180. CAL. Bus. \& Prof. CODE $\S 2507$ (a)(8) (West 2014).

181. Id. $\S 2508(\mathrm{a})(12)$.

182. Id. $\S 2507(\mathrm{c})(2)$.

183. Lisa Renner, New Independence for California Midwives, CALIFORNIA HEALTH REPORT (Dec. 18, 2013), http://www.healthycal.org/archives/14240, archived at http://perma.cc/GM6N9R8Q.

184. Id.

185. Id.

186. See Fisch, supra note 28, at 117-18 (explaining the benefits of a cooperative relationship).

187. Id. 
midwifery community, and California families resulted in successful change from which families wanting the homebirth experience and the midwifery model of care win.

3. States That Do Not Regulate Direct Entry Midwifery.-Ten states do not regulate Direct Entry Midwifery but allow the practice within its borders through either judicial interpretation or statutory inference. ${ }^{188}$ Four states neither legally define Direct Entry Midwifery nor prohibit it, leaving it unregulated. ${ }^{189}$ This lack of regulation and guidance is problematic for all birth attendants, including obstetricians, midwives, and women seeking options for childbirth. Even though the practice of Direct Entry Midwifery is not explicitly prohibited, DEMs potentially face charges of unlawfully practicing medicine if they use certain emergency interventions before getting their patients to the hospital. ${ }^{190}$ Furthermore, without any required training, anyone may call him or herself a DEM while lacking the essential skills needed for safe childbirth. ${ }^{191}$

4. States that Prohibit Direct Entry Midwifery.- - Seven states and the District of Columbia prohibit Direct Entry Midwifery through statute, judicial interpretation, or stricture of practice. ${ }^{192}$ Two states do not prohibit Direct Entry Midwifery by statute but prohibit its practice by making licensure unavailable. ${ }^{193}$ Until July 2013, Indiana also prohibited Direct Entry Midwifery. The debate between opponents and supporters of legalization is a fierce one, with opponents citing safety reasons for keeping DEMs illegal, and supporters calling on state legislatures to respect the deep tradition of midwifery. ${ }^{194}$ Despite their illegal

188. ME. REV. STAT. TIT. 32, § 13811 (2013) (recognizing and approving of CPMs); Miss. CODE ANN. § 73-25-33 (2013) ("nothing in [the practice of medicine act] shall apply to females engaged solely in the practice of midwifery"); MO. ANN. STAT. $\$ 376.1753$ (West 2013) (legalizing practice of tocology for a person with a certification by an organization accredited by the National Organization of Competency Assurance); Albini v. Conn. Med. Examining Bd., 72 A.3d 1208, 1214-17 (Conn. App. Ct. 2013) (holding that the practice of midwifery is not the practice of medicine); State Bd. of Nursing v. Ruebke, 913 P.2d 142, 156 (Kan. 1996) (holding that the practice of medicine does not include a midwife's aiding in childbirth); see also State Legal Status, supra note 133.

189. See State Legal Status, supra note 133 (showing that Hawaii, Nebraska, Ohio, and West Virginia leave Direct Entry Midwifery unregulated).

190. Hermer, supra note 23, at 355.

191. Marquardt, supra note 22, at 612.

192. 415 ILl. COMP. STAT. 60/3 (2013) (prohibiting Direct Entry Midwifery through its practice of medicine act); IOWA CODE $\S \S 147.2$, 148.1 (2013) (same); KY. REV. STAT. ANN. $\S$ 311.560 (2013) (same); MD. CodE ANN., Health Occup. § 14-301 (2013); N.C. GEN. STAT. §§ 90178.1 to -.7 (2013) (prohibiting Direct Entry Midwifery through its Midwifery statute and only allowing CNMs); 49 PA. CONS. STAT. § 16.11 (2013) (prohibiting Direct Entry Midwifery through its practice of medicine act); S.D. CodIFIED LAws $\S 36-4-8$ (2013) (same); D.C. CodE $\S 7-$ 751.01(6) (2013) (excluding DEMs from its definition of "other health professional").

193. Ala. CODE $\S 34-19-3$ (2013); GA. CODE ANN. § 31-26-1 to -7 (2013).

194. Rausch, supra note 16, at 234. 
status, many DEMs practice underground in these states. ${ }^{195}$ Prohibiting the practice of Direct Entry Midwifery is the antithesis of promoting a cooperative relationship between physicians and midwives and a dual system of childbirth for American women.

\section{B. Possible Constitutional Challenges to Direct Entry Midwifery Regulation}

Even though very few midwives will be able to fulfill the CDEM requirements to practice legally in the state of Indiana, it is unlikely that those wishing to increase the number of CDEMs can successfully change the law through constitutional challenges before the Indiana courts. The United States Supreme Court and the Indiana Supreme Court have not addressed the issue of whether a woman has maternal rights in birthing, such as the right to choose a birth attendant, but several other state courts of last resort have responded and answered in similar fashion. ${ }^{196}$ No court has been asked to address a hybrid-rights exception claim in which a free exercise claim is accompanied by a right to privacy claim, but this novel constitutional analysis is worth exploring. ${ }^{197}$ Perhaps as a consequence of the uncertainty of birthing rights and midwives' role surrounding these rights, prosecutions against midwives have been brought in half of the states. ${ }^{198}$ By understanding what avenues exist to successfully change Indiana's midwifery law, and what avenues will be almost certainly unsuccessful, midwifery advocates will be able to most effectively change Indiana's law to increase the number of capable, willing, and legal CDEMs in the state. ${ }^{199}$

1. Fundamental Right Challenge: Fundamental Right to Privacy.Uncertified Direct Entry Midwives may choose to challenge the Indiana law as

195. $I d$.

196. Marquardt, supra note 22, at 619-20.

197. See infra Part II.B.3.

198. Rausch, supra note 16, at 236-38 (including prosecutions for practicing medicine, nursing, or nurse-midwifery without a license).

199. Several cases exist in which a midwifery advocate successfully challenged a state's practice of medicine act, or functional equivalent, as void for vagueness. The states did not regulate Direct Entry Midwifery in any way. Because Indiana has an extensive and detailed certified direct entry midwifery law, those cases are inapplicable to this Note and will not be discussed in detail. See Albini v. Conn. Med. Examining Bd., 72 A.3d 1208, 1214-17 (Conn. App. Ct. 2013) (holding that the practice of midwifery is not the practice of medicine and should not be regulated by the Medical Examining Board); Peckmann v. Thompson, 745 F. Supp. 1388, 1393 (C.D. Ill. 1990) (holding that the Illinois Medicine Practices Act was unconstitutionally vague with respect to midwifery); Leggett v. Tenn. Bd. of Nursing, 612 S.W. 476, 481 (Tenn. Ct. App. 1981) (holding that the practice of midwifery was not the practice of medicine and the Board of Nursing could not punish a nurse acting as a lay midwife); $c f$. State v. Kimpel, 665 So. 2d 990, 993 (Ala. Crim. App. 1995) (denying the void for vagueness challenge and upholding the state's law prohibiting the practice of both nurse and lay midwifery); State ex rel. Mo. State Bd. of Registration for Healing Arts v. Southworth, 704 S.W.2d 219, 223-24 (Mo. 1986) (holding that the state's law prohibiting the practice of midwifery without a license was not void for vagueness). 
unconstitutional for violating an expectant mother's right to privacy. The right to privacy, a constitutional right derived from the First, Fourth, Ninth, and Fourteenth Amendments, protects personal choices pertaining to child-rearing, marriage, procreation, and abortion. ${ }^{200}$ Accused of practicing midwifery illegally, several DEMs have argued that a woman's fundamental right to privacy includes the freedom to choose whom to assist in childbirth; therefore, the midwifery laws should be analyzed using strict scrutiny. ${ }^{201}$

No court has accepted this argument. ${ }^{202}$ The court in Bowland v. Municipal Court for Santa Cruz County Judicial District ${ }^{23}$ was the first to address this claim. In rejecting the midwives' assertion that the freedom to choose one's childbirth attendant is fundamental as encompassed in the right to privacy, the court explained that "the right of privacy has never been interpreted so broadly as to protect a woman's choice of the manner and circumstances in which her baby is born." 204 It noted that Roe v. Wade ${ }^{205}$ and its progeny had specifically excluded the right to make these birthing choices from the privacy right. ${ }^{206}$ In the context of abortion, these cases have held that at the point of the fetus's viability, well before childbirth, the state's interest in the life of the unborn child supersedes the woman's privacy right in her own body. ${ }^{207}$ The Bowland court concluded that these policy reasons for the prohibition of abortion after viability extend to the requirement that those assisting in childbirth have valid licenses: the legislature may require midwives to be properly trained to protect the safety and welfare of their patients. ${ }^{208}$ Thus, the court held that the right to choose whomever one wants to assist in childbirth is not fundamental, and the law regulating midwifery should be analyzed using rational basis review. ${ }^{209}$

Subsequent courts considering a mother's right to choose who will assist in childbirth have applied similar reasoning and reached the same result. The court in Leigh v. Board of Registration in Nursing further explained the relationship between a woman's right to privacy post-viability and the state's interest in

200. Bowland v. Mun. Court for Santa Cruz Cnty. Judicial Dist., 556 P.2d 1081, 1089 (Cal. 1976).

201. See, e.g., Kimpel, 665 So.2d at 994; Bowland, 556 P.2d at 1088-89; People v. Rosburg, 805 P.2d 432, 437 (Colo. 1991); Hunter v. State, 676 A.2d 968, 975 (Md. Ct. Spec. App. 1996); Leigh v. Bd. of Registration in Nursing, 506 N.E.2d 91, 93-94 (Mass. 1987).

202. See, e.g., Kimpel, 665 So. $2 \mathrm{~d}$ at 994; Bowland, 556 P.2d at 1089; Rosburg, 805 P.2d at 437; Hunter, 676 A.2d at 975; Leigh, 506 N.E.2d at 94.

203. Bowland, 556 P.2d at 1089.

204. Id.; see David M. Smolin, The Jurisprudence of Privacy in a Splintered Supreme Court, 75 MARQ. L. REV. 975, 1011 (1992) ("The court's implicit statement that the right to abort is narrower than the right to choose the 'manner and circumstances' of birth is illogical. Both undergoing an abortion and employing a midwife are choices concerning childbirth.”).

205. Roe v. Wade, 410 U.S. 113 (1973).

206. Bowland, 556 P.2d at 1089.

207. Id.

208. Id.

209. Id. 
protecting the health and safety of both child and mother:

The statute does not require women to give birth in a hospital, nor does it force women to obtain medical treatment. The statute simply requires nurses who practice in the expanded role of midwife to be licensed and to practice in a licensed facility as part of a health care team. The statute does not interfere with any "fundamental right" established by Roe and its progeny. ${ }^{210}$

Because any privacy challenge to Indiana's law would hinge on the right of a woman to decide who attends her childbirth being a fundamental right and this argument has been repeatedly rejected by courts in other jurisdictions, any attempt to argue this right as fundamental to receive strict scrutiny analysis will almost certainly fail. ${ }^{211}$

2. Due Process Challenge: Right to Practice in a Chosen Profession.-The right to practice a chosen profession is a property interest protected by the Fifth and Fourteenth Amendments; therefore, state laws restricting this right must be rationally related to a legitimate state interest. ${ }^{212}$ Sammon v. New Jersey Board of Medical Examiners ${ }^{213}$ is particularly helpful in analyzing the effectiveness of a due process challenge to Indiana's law because New Jersey's Midwifery statute is similar to Indiana's statute, as both require state regulated Direct Entry midwives to pass an examination, complete midwifery education or some functional equivalent, and obtain proof of physician endorsement in the case of New Jersey and physician collaboration in the case of Indiana. ${ }^{214}$ Several unlicensed midwives and parents wishing to use their services in childbirth filed suit claiming that the New Jersey statute violated their due process rights under the Fourteenth Amendment. ${ }^{215}$ After settling issues of standing, the Third Circuit addressed the midwives' complaint that the statute unconstitutionally deprived them of their ability to earn a living in their chosen profession and that the statute makes it practically impossible for direct entry midwives to obtain licenses. ${ }^{216}$ The court found that the midwives' interests in practicing their chosen profession were not fundamental and applied rational basis review. ${ }^{217}$

To survive rational basis review, the state must identify a legitimate state interest that the legislature rationally could conclude was served by the statute. ${ }^{218}$ The Third Circuit found that the state interests in protecting the health and

210. Leigh v. Bd. of Registration in Nursing, 506 N.E.2d 91, 94 (Mass. 1987).

211. See State v. Kimpel, 665 So. 2d 990, 994 (Ala. Crim. App. 1995); Bowland, 556 P.2d at 1089; People v. Rosburg, 805 P.2d 432, 437 (Colo. 1991); Leigh, 506 N.E.2d at 94.

212. Lange-Kessler v. Dep't of Educ. of the State of N.Y., 109 F.3d 137, 140 (2d Cir. 1997).

213. 66 F.3d 639 (3d Cir. 1995).

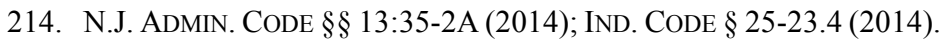

215. Sammon, 66 F.3d at 640-41.

216. Id. at 645 .

217. Id.

218. Id. 
welfare of the mother and child were legitimate. ${ }^{219}$ Furthermore, it found that the regulatory scheme designed to assure that DEMs are qualified was rationally related to the state interest. ${ }^{220}$ Regarding the physician supervision requirement, the court acknowledged that this requirement may make it more difficult for DEMs to obtain licenses but noted that soliciting physicians' views on potential midwifery candidates is not irrational. ${ }^{221}$ Disputes of fact, such as the safety of properly trained but unlicensed midwives, are not legally relevant under a substantive due process analysis. ${ }^{222}$ Thus, the court upheld the New Jersey state law. ${ }^{223}$ Given the similarity between Indiana's midwifery law and New Jersey's midwifery law and the consistency with which courts have rejected the due process challenge to midwifery regulation, ${ }^{224}$ a due process challenge to Indiana's law will also likely fail.

3. First Amendment Challenge: The Hybrid-Rights Exception.-Unlike the fundamental rights challenge and the due process challenge, a first amendment challenge has never been asserted to defend an expectant mother's right to choose her childbirth attendant. The hybrid-rights exception, first presented in Employment Division, Department of Human Resources of Oregon v. Smith, ${ }^{225}$ provides a colorful argument to the constitutional implications of CDEM regulation on Indiana's significant Amish population. ${ }^{226}$ The Court in Smith pronounced that, as a general rule, a facially neutral and generally applicable law is constitutional, regardless of how the law affects the exercise of religion, and a compelling state interest need not justify such regulation. ${ }^{227}$ An exception to the

219. Id. at 646 .

220. Id.

221. Id. at 647.

222. Id.

223. Id.

224. See Bowland v. Mun. Court for Santa Cruz Cnty. Judicial Dist., 556 P.2d 1081, 1088 (Cal. 1976) ("The state ... clearly has a strong and demonstrable interest in protecting its citizens from persons who claim some expertise in the healing arts, but whose qualifications have not been established by the receipt of an appropriate certificate.”); Lange-Kessler v. Dep't of Educ. of the State of N.Y., 109 F.3d 137, 141 (2d Cir. 1997) (finding that the formal education and written practice agreement with a licensed physician was rationally related to the legitimate state interest of protecting the health and welfare of mothers and infants).

225. 494 U.S. 872, 881 (1990) ("The only decision in which we have held that the First Amendment bars application of a neutral, generally applicable law to religiously motivated action have involved not the Free Exercise Clause alone, but the Free Exercise Clause in conjunction with other constitutional protections, such as freedom of speech and of the press or the right of parents to direct the education of their children.") (citations omitted).

226. See Molly Manns, Indiana's Amish Population, IN CONTEXT (Dec. 2012), http://www.incontext.indiana.edu/2012/nov-dec/article2.asp, archived at http://perma.cc/Q7VLPAEE (noting that 45,144 Amish adherents live in Indiana, which comprises nineteen percent of the Amish in the United States as a whole).

227. Ryan M. Akers, Begging the High Court for Clarification: Hybrid Rights Under Employment Division v. Smith, 17 REGENT U. L. REV. 77, 80 (2005). 
general rule exists in which courts should use strict scrutiny analysis in hybrid situations where litigants couple a free exercise claim with another constitutional claim. ${ }^{228}$ The Court used a previous case, Wisconsin v. Yoder, ${ }^{229}$ as the basis for the hybrid-rights exception. ${ }^{230}$ In Yoder, the Court upheld claims of free exercise and the right to control the education of one's children using strict scrutiny analysis and granted Amish parents an exemption from compulsory school laws for their minor children. ${ }^{231}$ The hybrid-rights exception elicited heated debate from scholars and resulted in varied outcomes from courts. ${ }^{232}$ The Seventh Circuit addressed this issue in Civil Liberties for Urban Believers v. City of Chicago. ${ }^{233}$ It explained that a hybrid-rights claim requires a strict scrutiny analysis, but it found that the plaintiffs' accompanying claims lacked merit. ${ }^{234}$ Thus, it is unclear what approach the Seventh Circuit adopted. ${ }^{235}$

Indiana's CDEM statute is a neutral law of general applicability, as it applies to all Hoosiers equally regardless of religious affiliation. ${ }^{236}$ Certain conservative Old Order Amish families and communities firmly believe that childbirth should occur naturally in the home. ${ }^{237}$ Because only few qualified DEMs will be able to

228. Hope Lu, Addressing the Hybrid-Rights Exception: How the Colorable-Plus Approach Can Revive the Free Exercise Clause, 63 CASE W. RES. L. REV. 257, 263 (2012).

229. 406 U.S. 205 (1972).

230. Lu, supra note 228, at 263-64.

231. Id. (citing Yoder, 406 U.S. at 235-36).

232. Id. at 265-71 (explaining that some courts dismiss the hybrid-rights exception as dicta and refuse to recognize the exception until the United States Supreme Court provides more direction, some courts apply strict scrutiny only when an independently viable constitutional claim accompanies a free exercise claim, other courts apply strict scrutiny only when a colorable claim that an additional constitutional right has been violated accompanies a free exercise claim, and still other courts apply a variation of these previously listed approaches).

233. 342 F.3d 752, 764-65 (7th. Cir. 2003).

234. Id. at 765 (quoting Miller v. Reed, 176 F.3d 1202, 1207-08 (9th. Cir. 1999)) (explaining that the court found that the plaintiffs' freedom of speech, freedom of assembly, and equal protection claims lacked merit and that "a plaintiff does not allege a hybrid rights claim entitled to strict scrutiny analysis merely by combining a free exercise claim with an utterly meritless claim of the violation of another alleged fundamental right").

235. John L. Tuttle, Note, Adding Color: An Argument for the Colorable Showing Approach to Hybrid Rights Claims Under Employment Division v. Smith, 3 AVE MARIA L. REV. 741, 763 (2005).

236. Cf. Emp't Div., Dep't of Human Res. of Or. v. Smith, 494 U.S. 872, 878-79 (1990) (concluding that Oregon's statute prohibiting knowing or intentional possession of a controlled substance was a neutral law of general applicability, even when applied to the religious use of peyote); Wisconsin v. Yoder, 406 U.S. 205, 213-14 (1972) (concluding that Wisconsin's schooling requirements and regulations were neutral laws of general applicability, even when applied to Amish parent's religious objections).

237. Donald B. Kraybill, The Amish and the State 177-78 (2003); see also Pamela Edith Klassen, Blessed Events: Religion AND Home Birth In AMERICA 115 (2001) (“Amish women interpret their choice to give birth at home as a practice in continuity with their daily lives 
practice legally in Indiana, ${ }^{238}$ it is possible that an expectant mother in a rural, Amish community will be unable to locate a CDEM to assist in her homebirth. If a litigant challenged the statute by either a free exercise claim or a right to privacy claim from this Amish adherent, the court would simply apply rational basis review, and uphold the statute. ${ }^{239}$ If the expectant mother used the alternative route of the hybrid-rights exception and asserted a free exercise claim accompanied by a right to privacy claim, however, her claim could potentially receive a strict scrutiny analysis, and the court would strike the statute down. ${ }^{240}$

\section{AN UNWORKABLE STATUTE}

Indiana recently legalized the practice of Direct Entry Midwifery for the first time. $^{241}$ In a push to legalize and regulate these midwives, for the past twenty years, Indiana state legislators brought bills before the legislature. ${ }^{242}$ Some of the strongest support for legalizing Direct Entry Midwifery came from members of the Amish community, who opposed hospital births for religious reasons and desired a safe, regulated alternative to hospital births in the form of midwife attended homebirths. ${ }^{243}$ Despite the infancy of the new law, midwives performed homebirths in Indiana for hundreds of years. ${ }^{244}$ The Indiana State Department of Health reported that there were 1058 intended live births at home in 2010, and of those births, only 357 were assisted by Certified Nurse Midwives. ${ }^{245}$ In 2010, Certified Nurse Midwifery was the only type of midwifery legal in Indiana, which means that the remaining 701 intended homebirths were either attended by a DEM or planned as a freebirth. ${ }^{246}$ State Representative Ed Clere, chairman of the

(and hence their religion).").

238. See infra Part III.B.

239. See Smith, 494 U.S. at 878-79 ("We have never held that an individual's religious beliefs excuse him from compliance with an otherwise valid law prohibiting conduct that the State is free to regulate."); see generally Part II.B.1-2 (analyzing right to privacy claims in the context of midwifery regulation using rational basis review).

240. See Smith, 494 U.S. at 881 (explaining the hybrid-rights exception).

241. See State v. Smith, 459 N.E.2d 401, 405 (Ind. 1984) ("[T]he practice of midwifery without a license would constitute the unauthorized practice of medicine.").

242. Price, supra note 4.

243. Hayden, supra note 3.

244. Id.

245. Niki Kelly, Panel Approves Stricter Rules in Midwife Bill, J. GAZETTE (Apr. 4, 2013, 10:36 AM), http://www.journalgazette.net/article/20130404/LOCAL/304049949/-1/local11, archived at http://perma.cc/6GX3-BSHY; see also Dann Denny, More Hoosier Parents Choosing to Give Birth at Home, with the Help of a Midwife, IND. ECON. DIG. (Oct. 19, 2011, 9:49 AM), http:/www.indianaeconomicdigest.net/main.asp?SectionID=31\&SubSectionID=120\&ArticleID $=62220$, archived at $\mathrm{http}: / /$ perma.cc $/ \mathrm{Z} 26 \mathrm{U}-2 \mathrm{X} 6 \mathrm{H}$ (estimating that 1000 Hoosier women give birth at home every year, usually with the assistance of a midwife).

246. See Anna Hickman, Note, Born (Not So) Free: Legal Limits on the Practice of Unassisted Childbirth or Freebirthing in the United States, 94 MINN. L. REV. 1651, 1652-53 (2010) 
House Public Health Committee, put the significance of the new midwifery law in perspective: "This is not creating a new practice of midwifery . . . The practice has been going on in Indiana since the frontier days. All this does is make it safer and more transparent." 247

\section{A. A Review of Indiana's Certified Direct Entry Midwifery Statute}

Before dissecting the strengths and weaknesses of Indiana's Certified Direct Midwifery Statute, ${ }^{248}$ it is necessary to highlight some of its provisions for purposes of this Note's discussion. Practicing midwifery without a certificate is a Class D felony, ${ }^{249}$ and the Indiana Medical Licensing Board is responsible for certifying CDEMs. ${ }^{250}$ Rather than recognizing and adopting standards set forth by the National Association of Certified Professional Midwives, the Indiana legislature created its own standards and title in the Certified Direct Entry Midwife. ${ }^{251}$ To practice legally, a CDEM candidate must complete a certain level of education ${ }^{252}$ and maintain sufficient liability insurance ${ }^{253}$ to receive a certificate, and, in addition to the certificate, a CDEM must have a collaborative agreement with a supervising physician. ${ }^{254}$

"Physician collaboration" mandates that the physician shall review all patient encounters that the CDEM has with a patient at any time requested by the physician and once during the first and third trimester, and the percentage of charts that the physician must review is set forth in the statute based on the CDEM's experience. ${ }^{255}$ Collaboration with a CDEM does not require the physical presence of the physician at the time and place at which the CDEM renders services, ${ }^{256}$ but the physician must be located in an area close to where the delivery will occur. ${ }^{257}$ The patient must sign an informed disclosure of practice

(defining freebirthing, or unassisted childbirth, as giving birth without a physician or a midwife in attendance).

247. Hayden, supra note 3.

248. IND. CODE $\S 25-23.4$ (2014).

249. Id. § 25-23.4-3-7(b).

250. Id. $\S 25-23.4-2-6$.

251. Id. $\S 25-23 \cdot 4-1-4$

252. Id. § 25-23.4-3-1(c) (requiring that CDEMs possess either an associate degree in nursing, associate degree in midwifery accredited by the Midwifery Education Accreditation Council ("MEAC"), or a bachelor's degree from a postsecondary education institution and that CDEMs satisfactorily complete all requirements of the CPM); $c f$. CERTIFIED PROFESSIONAL MidWIFE: CANDIDATE INFORMATION BOOKLET, N. A.M. REgISTRY OF MidWIVES (2013) (requiring no postsecondary degree).

253. IND. CODE $§ 25-23.4-3-1$ (c)(10) (2014).

254. Id. § 25-23.4-3-1(b)(2).

255. Id. $\S 25-23.4-5-1(\mathrm{~b})$.

256. Id. $\S 25 \cdot 23.4-5-1(\mathrm{a})$.

257. Id. $\S 25.23 .4-4-1$ (a)(6); see also Kelly, supra note 245 (noting that the provisions in the CDEM statute are similar to those concerning the physician assistant-physician relationship). 
form in which the patient agrees to waive her right to sue a physician, health care provider, or the hospital for the acts of the CDEM. ${ }^{258}$ This provision appears to shield the physician from vicarious liability from the actions of the CDEM, but the physician may still be liable for the care she provides directly to the patient.

The CDEM statute requires a CDEM to refer an at-risk or emergency patient to a physician for consultation. ${ }^{259}$ Most obstetricians practice in a hospital setting, yet the statute leaves the decision of whether to extend clinical privileges to CDEMs up to the hospital. ${ }^{260}$ When referring an at-risk patient to a physician for consultation, the CDEM could lose her ability to be the patient's primary care provider. Similar to consulting physicians, courts may not hold hospitals jointly or severally liable for the acts or omissions of a CDEM. ${ }^{261}$

\section{B. Why the CDEM Statute Will Prove Unworkable}

Ultimately, Indiana's CDEM statute will prove unworkable and fall short of the legislature's goal to safely and effectively regulate DEMs. ${ }^{262}$ Specifically, the physician collaboration requirement and the insurance maintenance requirement will prevent many otherwise qualified DEMs from practicing legally. ${ }^{263}$ Without a workable statute, the illegal practice of midwifery will continue, much as it had before the passing of the statute. ${ }^{264}$ A DEM practicing without a certificate and a collaborative agreement risks criminal prosecution ${ }^{265}$ and will be hesitant to consult with a physician. ${ }^{266}$ The CDEM statute forces women who wish to have a homebirth with a CDEM for personal or religious reasons to use the services of a DEM illegally, deliver in a hospital, or pursue a hybrid-rights claim, the result of which is uncertain. ${ }^{267}$ This reality is the antithesis of the desired dual system of childbirth care, in which DEMs care for women with low-risk pregnancies and physicians care for women with high-risk pregnancies, and the two communities work together for the health of Hoosier women. ${ }^{268}$ By examining why these two

258. IND. CODE $\S 25-23.4-4-3(14)$ (2014).

259. Id. § 25-23.4-4-3(11).

260. Id. $\S 25-23.4-7-1$.

261. Id. $\S 25-23.4-8-1$.

262. Cf. Hermer, supra note 23, at 354 (noting the same result in California).

263. Cf. id. (explaining the same result in California from California's physician supervision requirement); State of Colo. DeP'T OF REgUlatory AgENCIES, LiabiLITy INSURANCE FOR DiRECT ENTRY MidWIVES (2011) [hereinafter COLORADO LiABILITY INSURANCE] (finding no sufficient liability insurance for its registered DEMs).

264. Cf. Hermer, supra note 23, at 354 (noting the same result in California).

265. See, e.g., Scott Weissner, Woman Pleads to Unlawful Midwifery, Goshen News (Feb. 19, 2014), http://www.goshennews.com/local/x1196445797/Woman-pleads-to-unlawful-midwifery, archived at http://perma.cc/3NYN-8MVK (entering a guilty plea to unlawful practice of medicine and facing a 330-day sentence and probation).

266. Tovino, supra note 19, at 96 (finding the same result in California).

267. See supra Part II.B.3.

268. Fisch, supra note 28, at 116. 
sections of Indiana's CDEM statute could be a legal barrier to render the law unworkable and how the legislature can amend that statute, the state could offer Hoosier families the safe, cost-effective option of CDEM-assisted childbirth aimed for by the state legislators. ${ }^{269}$

The current Indiana CDEM statute creates a reality in which these midwives depend on physicians to work and strips them of any sort of autonomy in their midwifery practice. ${ }^{270}$ Furthermore, midwives living in rural areas of Indiana have a limited number of physicians from whom to seek this collaborative relationship. ${ }^{271}$ As a result, the offer of state certification will likely be more of an illusory one because only a very small number of physicians will be willing to enter into the required collaborative agreement. ${ }^{272}$ Indeed, this problematic situation occurred in California, whose DEMs were subject to a similar provision. ${ }^{273}$ The lack of official physician-DEM relationships and the pervasive presence of unofficial physician-DEM relationships even led the California Department of Medicine to cease punishing those DEMs not in an official relationship with a physician. ${ }^{274}$ The California legislature listened to the medical and midwifery communities alike to remove the supervision requirement. ${ }^{275}$

It is understandable that, because of the perceived risk of liability, an obstetrician might be extremely hesitant to become part of the collaborative relationship with a CDEM. The statute attempts to protect physicians from vicarious liability claims, ${ }^{276}$ but the physician can still be liable for the treatment the physician provides directly to the patient. ${ }^{277}$ Furthermore, malpractice insurance carriers may not allow physicians to engage in formal collaborative relationships with CDEMs. ${ }^{278}$ The perceived liability and malpractice insurance

269. Cf. Tovino, supra note 19, at 97 (explaining how California amended its midwifery statute to achieve a workable statute).

270. Fisch, supra note 28, at 104.

271. IND. CODE $§ 25.23 .4-4-1$ (a)(6) (2014) ("The collaborating physician should be located in an area close to where the delivery will occur."); see Indiana Tangles with Shortage of Rural Doctors, HERALD BULLETIN (June 23, 2013), http://www.heraldbulletin.com/breakingnews/ x493358090/Indiana-tangles-with-shortage-of-rural-doctors, archived at http://perma.cc/9EMKFGWZ [hereinafter Rural Doctors] (noting the shortage of physicians in rural areas of Indiana).

272. Cf. Hermer, supra note 23, at 354 (noting the same result in California).

273. Id.

274. Tovino, supra note 19 , at 63.

275. A.B. 1308, 2013-2014 Reg. Sess. (CA 2013); CA Bus. \& Prof. CodE $§ 2507-08$ (2014).

276. IND. CODE $§ 25-23.4-4-3(14)$ (2014) ("The informed disclosure of practice form must . . contain the following information .... A statement that the client understands that the client is waiving the right to sue a physician or health care provider for the acts of omissions of the client's certified direct entry midwife.").

277. Kimberly A. Emil, Indiana's New Certified Direct Entry Midwife Law Takes Effect July 1, 2013, HALl, Render, Killian, HeAth \& Lyman, P.C.: Litigation ANALYsis (June 14, 2013), http://blogs.hallrender.com/litigation/2013/06/14/indianas-new-certified-direct-entry-midwife-lawtakes-effect-july-1-2013/, archived at http://perma.cc/VYV5-Y4R2.

278. See Hermer, supra note 23, at 354 (noting that most California obstetricians were unable 
issues will likely be the biggest hurdle for CDEMs to overcome in their attempts to satisfy the collaboration agreement requirement, but many physicians' personal opinions of these midwives will also make physicians reluctant to enter into the collaboration relationship. ${ }^{279}$ One Hoosier obstetrician acknowledged that most homebirths occur free of complications, but when homebirths do go wrong, obstetricians "see the worst of the worst .... We have a skewed perspective."280 She "know[s] people who have had home births and had a wonderful experience. It sounds really nice, and 90 percent of the time they go well . . . [But w] hat's your backup plan?"281 On paper, Indiana's physician collaboration requirement appears to provide an answer to this obstetrician's question; however, in reality, the result of this collaboration requirement will be a large number of midwives practicing illegally, who are not subject to the standard of care as outlined in the statute and who will avoid any sort of relationship with physicians. ${ }^{282}$ The midwifery community will continue to be on the fringe of the maternal health community, much like when Direct Entry Midwifery was illegal. ${ }^{283}$

The issue of liability insurance maintenance has a more uncertain impact on the workability of Indiana's CDEM statute, ${ }^{284}$ but it will likely hinder and prevent many otherwise qualified midwives from practicing. Colorado law does not presently require DEMs to carry liability insurance; however, once the state is able to find affordable liability insurance, the state will require its registered DEMs to carry that insurance. ${ }^{285}$ The Colorado legislature passed this law in 2006, but the Colorado Division of Registrations has yet to find affordable liability insurance. ${ }^{286}$ If the members of Colorado's government cannot locate liability insurance at an affordable price, it is unlikely that Indiana's DEMs, who are probably not well-versed in insurance shopping, will be able to find sufficient, affordable liability insurance. ${ }^{287}$ Thus, mandating CDEMs to enter into a physician collaboration agreement and maintain sufficient liability insurance will likely impose unintended legal barriers to the creation of a dual system of childbirth care and will evade the legislature's goal of legalizing Certified Direct Entry Midwifery and giving Hoosier mothers a safe, regulated alternative to physician-attended hospital births. ${ }^{288}$

to supervise DEMs because their malpractice insurance carrier did not allow it).

279. See, e.g., Emily Campion, Home Birth Supporters Praise New Indiana Law, CHESTERTON TRIB. (June 13, 2013), http://www.chestertontribune.com/Indiana\%20News/home_birth_ supporters_praise_new.htm, archived at http://perma.cc/8GFD-MJEM.

280. Id.

281. $I d$.

282. Cf. Tovino, supra note 19, at 95 (finding the same trend in California).

283. Cf. White, supra note 174, at $1 \mathrm{~A}$ (explaining the same result in California).

284. No other state requires DEMs to maintain sufficient liability insurance, so it is difficult to find answers elsewhere.

285. Colo. ReV. Stat. § 12-39-109(3) (2014).

286. COLORADO Liability InSURANCE, supra note 263.

287. Cf. id.

288. See Proposed HB 1135, Committee on Public Health Report (Feb. 18, 2013), 


\section{Moving Forward}

With a few amendments to Indiana's Certified Direct Entry Midwifery statute, the state legislature can honor Hoosier women's choices to plan homebirths with the help of CDEMs in a safe, regulated, and effective manner. The Indiana legislature effectively delineates the scope of practice for Certified Direct Entry Midwifery through the statute and requires a level of education of CDEMs that could instill respect for CDEMs throughout the state. One Hoosier midwife comments, "[w] believe strongly in our responsibility to be accountable for people in our state .... We appreciate stringent educational requirements for midwives. That's fine, that's good. That's in the interest of families who hire us . . .."289 The statute should enable these midwives to receive certificates and practice legally. It should recognize that "[p]lanned home births are safer when care is provided as part of a collaborative delivery model in which medical professionals may freely consult on patient care to maximize patient safety and positive outcomes." 290 The current physician collaboration agreement and maintenance of sufficient liability insurance requirements do not advance this goal. ${ }^{291}$

The legislature should remove the physician collaboration requirement. Instead, it should encourage CDEMs and obstetricians to collaborate informally. ${ }^{292}$ Given the shortage of physicians in rural areas of Indiana ${ }^{293}$ and the many Amish communities throughout the state, ${ }^{294}$ it is especially important to give otherwise qualified midwives the chance to practice legally with the necessary degree of independence. ${ }^{295}$ An Amish woman's United States Constitutional rights to free exercise of religion and of privacy are at stake. ${ }^{296}$ Thus, removing the physician collaboration requirement will assure Hoosier mothers, Amish or otherwise, that they can have their low-risk pregnancy assisted

http://www.in.gov/legislative/bills/2013/HCRF/AM113503.001.html, archived at http://perma.cc/LKV7-UEJS [hereinafter Proposed HB 1135] (requiring CDEMs to maintain sufficient liability insurance "if the board finds: (A) liability insurance is available to [CDEMs] in Indiana; and (B) the cost of liability insurance is comparable to the cost of liability insurance for licensed home birth midwives in other states," but the committee rejected this version of HB 1135) (emphasis added).

289. Campion, supra note 279.

290. A.B. 1308, 2013-2014 Reg. Sess. (CA 2013).

291. See supra Part III.B.

292. See, e.g., Arkansas State BoArd of Health, supra note 147, 500.

293. Rural Doctors, supra note 271.

294. Manns, supra note 226.

295. See Smolin, supra note 204, at 1009 ("states containing numerous counties with no available hospitals and no available physicians have nonetheless overregulated or prohibited midwifery, leaving rural women with no prenatal and birthing care within a reasonable distance of their homes").

296. See Part II.B.3. 
by a CDEM and that, if something does go wrong during homebirths, they will be able to be brought to a physician.

Although the midwifery community and the medical community still approach childbirth differently, a recent press release from ACOG paves the way to the existence of a strong and respectful relationship between them. ${ }^{297}$ In February 2011, it noted that the organization "believes that hospitals and birthing centers are the safest setting for birth, [but] it respects the right of a woman to make a medically informed decision about delivery." 298 To continue developing this informal collaborative relationship, however, an effective Indiana statute needs to include specific language shielding the collaborative physician from liability. ${ }^{299}$ The current statute only requires a statement in the informed consent form that the patient understands she is waiving her right to sue a physician for the acts or omissions of the CDEM, ${ }^{300}$ which does not sufficiently shield the physician from liability as a jury could be unable to separate harm caused by the physician from harm caused by the CDEM..$^{301}$ The Committee on Public Health introduced a version of the CDEM statute that provided the necessary protection for physicians, but the version was ultimately rejected. ${ }^{302}$ The statute needs to include specific language that physicians who choose either to collaborate informally with CDEMs or to care for CDEM patients on an emergency basis are immune from liability in the absence of a physician's grossly reckless behavior. ${ }^{303}$ Without such liability protection, DEMs have virtually no chance of fostering the collaborative relationship that will make childbirth safest for Hoosier women. ${ }^{304}$

Additionally, the Indiana legislature should remove the requirement that CDEMs must maintain sufficient liability insurance for certification. Ideally, of course, CDEMs will maintain sufficient liability insurance, but until the Indiana legislature or the Indiana Medical Licensing Board presents them with an affordable plan, the insurance requirement may prevent otherwise qualified DEMs from practicing legally in Indiana because many insurance plans will be extremely costly and unaffordable for an independent CDEM. As with the codification of protecting physicians from vicarious liability, the Committee on Public Health considered this "wait-and-see" approach, but this was ultimately rejected. ${ }^{305}$ The state legislature should also ensure that Hoosier women receiving health coverage through Medicaid are covered. This is an important issue in Indiana as forty-one percent of all births in the state are covered by Medicaid. ${ }^{306}$

297. ACOG Committee Opinion, supra note 96, at 1.

298. Id.

299. Fisch, supra note 28, at 111.

300. IND. CODE $\S 25-23.4-4-3(14)$ (2014).

301. Fisch, supra note 28, at 111 .

302. See Proposed HB 1135, supra note 288.

303. See, e.g., FLA. STAT. § 467.0017(2)(2014); IDAHO CODE ANN. § 54-5512 (2014); LA. REV. STAT. ANN. § 37:3244(B) (2014); N.M. CODE R. § 16.11.3.12 (2014).

304. Cf. Hermer, supra note 23, at 354 (noting the same result in California).

305. See Proposed HB 1135, supra note 288.

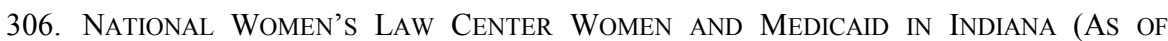




\section{CONCLUSION}

Although the CDEM statute produces results that surely no statute should produce, with a few amendments, the statute can affect the change aimed for by legislators, strengthen the relationships between physicians and midwives, and respect Hoosier women's constitutional rights. The current statute will simply prove unworkable, and very few otherwise qualified midwives will be able to practice legally and will likely continue to practice illegally in the state without a certificate or a collaborative agreement. In order to ensure that every Hoosier woman has access to a safe, regulated homebirth assisted by a CDEM with a strong professional relationship with a physician in a dual system of childbirth care, the Indiana legislature should amend the CDEM statute to achieve its stated purpose.

FEBRUARY 2010) (2010). 